\title{
1H-MR Spectroscopy Guided Gamma Knife Radiosurgery for Treatment of Glioma
}

\section{Gliom Tedavisinde 1H-MR Spektroskopi Rebberliğinde Gamma Buçă̆ı Radyocerrabisi}

\author{
Guangjian SHEN ${ }^{1}$, Lunshan XU' ${ }^{1}$, Minhui XU ${ }^{1}$, Minying GENG ${ }^{1}$, Yong TAN ${ }^{2}$, Feipeng $\mathrm{LI}^{1}$ \\ ${ }^{1}$ Research Institute of Surgery \& Daping Hospital, Third Military Medical University, Department of Neurosurgery, Chongqing 400042, \\ Chongqing, China \\ ${ }^{2}$ Research Institute of Surgery \& Daping Hospital, Third Military Medical University, Magnetic Resonance Imaging, Department of Radiology, \\ Chongqing, China
}

Correspondence address: Lunshan XU / E-mail: david0608@yeah.net

\begin{abstract}
AIM: To observe the outcomes of $1 \mathrm{H}$ - MR-spectroscopy (MRS) guided gamma knife surgery for treatment of glioma.

MATERIAL and METHODS: Twenty patients with glioma diagnosed pathologically were randomly divided into MRI group and MRI plus MRS group. The target volume was defined as the tumor enhanced area plus the surrounding area with a short T1 and a long T2 in the MRI group, while the tumor enhanced area plus the surrounding area with a short T1 and a long T2 and choline: $\mathrm{N}$-acetyl aspartate index (CNI) $\geq 1.6$ in the MRI plus MRS group.12 months after surgery were set as the endpoint.

RESULTS: Thirteen (65\%) patients were successfully treated, of whom 6 were in the MRI group and 7 in the MRI plus MRS group. Ten patients suffered from cerebral edema during treatment, including 8 in the MRI group and 2 in the other group. The cases of cerebral edema were significantly fewer in the MRI plus MRS group than the MRI group. The average maximum diameter of the target volume was smaller in the MRI plus MRS group.
\end{abstract}

CONCLUSION: The MRS-guided gamma knife radiosurgery helps to identify and remove the lesion of glioma and reduce complications due to extended surgical scope.

KEYWORDS: MR-spectroscopy, Gamma knife, Glioma

öz

AMAÇ: Gliom tedavisinde 1H-MR spektroskopi (MRS) rehberliğinde gamma bıçağı cerrahisinin sonuçlarını değerlendirmek.

YÖNTEM ve GEREÇLER: Patolojik olarak gliom tanısı konmuş yirmi hasta MRG grubu ve MRG artı MRS grubu olarak rastgele bölündü. Hedef hacim tümör kontrast madde tutan alanı artı çevresindeki MRG grubunda kısa T1 ve uzun T2 alan olarak değerlendirilirken MRG artı MRS grubunda ise tümör kontrast madde tutan alanı artı çevresindeki kısa T1 ve uzun T2 ve kolin:N-asetil aspartat indeksi (CNI) $\geq 1,6$ olan alandı. Cerrahiden 12 ay sonrası son nokta olarak belirlendi.

BULGULAR: On üç (\%65) hasta başarıyla tedavi edildi ve bunların 6'sı MRG grubunda ve 7'si MRG artı MRS grubundaydı. On hasta tedavi sırasında serebral ödem yaşadı ve bunların 8'i MRG grubunda ve 2'si diğer gruptaydı. Serebral ödem vakalarının sayısı MRG artı MRS grubunda MRG grubundan önemli ölçüde daha azdı. Hedef hacmin ortalama maksimum çapı MRG artı MRS grubunda daha küçüktü.

SONUÇ: MRS rehberli gamma bıçağı radyocerrahisi gliom lezyonunun tanımlanması ve çıkarılmasına ve genişletilmiş cerrahi kapsam sayesinde komplikasyonların azalmasına yardımcı olur.

ANAHTAR SÖZCÜKLER: MR spektroskopisi, Gamma bıçağı, Gliom

\section{INTRODUCTION}

Radiotherapy is a major treatment for glioma. However, because most gliomas are resistant to radiotherapy, only a high dose of irradiation can achieve desirable lesion control. The dosage cannot be ensured in fractionated external beam radiotherapy because normal tissues surrounding the lesion cannot tolerate it. In order to improve efficacy of radiotherapy, it is highly necessary to identify an approach for high dosage for the lesion. Radiosurgery is one of the choices for noninvasive, accurate and specific irradiation $(8,10)$.
For radiosurgery, the target area should be irradiated at the dose being less than the prescribed dose while the normal tissues should be protected with the settlement in the "falloff" dose area outside the target volume. Consequently it is vital to define the target volume. Since the glioma is characterized by malignant properties such as invasive growth, conventional MRI cannot delineate the target lesion, which in part compromises the application of gamma knife radiosurgery in clinical practice (5). 
Different pathological phases are typified by different metabolisms. For example, the reduction or loss of $\mathrm{N}$-acetyl aspartate (NAA) may be attributed to neuron damages, as it mainly exists in the neuron. Choline (Cho) is a component of phospholipid metabolism. When cellular membrane is disintegrated in tumor proliferation, its content may increased. Pathologic change may be distinguished through identification of these chemicals. MR spectroscopy (MRS) is such a technique taking into account chemical change. It analyzes nucleus and compounds based on magnetic resonance and chemical shift (14).

Accumulated evidence indicates that glioma is characterized by specific MRS features that are helpful for diagnosis and prognosis determination $(6,1,4)$. However little is reported about the utility of MRS in radiosurgery. In this study, we prospectively observed outcomes of 20 patients with glioma after gamma knife radiosurgery with or without MRS and investigated the feasibility of MRS guided gamma knife surgery for glioma.

\section{PATIENTS and METHODS}

\section{Patients}

A total of 20 patients treated in Department of Neurosurgery, Chongqing Daping Hospital from September 2008 to June 2010 were included. All patients were diagnosed as glioma confirmed by pathological examination. Clinical characteristics of the patients were summarized (Table I). There were 14 males and 6 females ranging in age between 16 and 76 years with an average of 43.7 years old. Thirteen patients were treated with chemotherapy prior to or after neurosurgery and 8 patients were irradiated by external beam(including all patients with WHO grade III / IV). Pathologic types of glioma included 12 cases of astrocytoma ( 8 with WHO grade I and II and 4 with WHO grade III and IV), 4 cases of ependymoma (2 with WHO Grade I and II and 2 with WHO grade III and IV), and 4 cases of oligodendrocyte ( 3 with WHO Grade I and II and 1 with WHO grade III and IV). The maximum diameter of

Table I: Clinical Characteristics of 20 Patients with Glioma

\begin{tabular}{|c|c|}
\hline Variables & Data \\
\hline Male patients (\%) & $14(70)$ \\
\hline Average age at treatment (range) & $40.7(16-76)$ \\
\hline External beam radiotherapy (\%) & $8(40)$ \\
\hline Patients with Prior chemotherapy (\%) & $13(65)$ \\
\hline \multicolumn{2}{|l|}{ Pathologic types (\%) } \\
\hline Neuroastrocytoma & $12(60)$ \\
\hline Ependymoma & $4(20)$ \\
\hline Oligodendrocyte & $4(20)$ \\
\hline \multicolumn{2}{|l|}{ Grading (\%) } \\
\hline WHO grade I and II & $13(65)$ \\
\hline WHO grade III and IV & $7(35)$ \\
\hline Maximum diameter of the target volume & $3.2(2.4-4.2 \mathrm{~cm})$ \\
\hline
\end{tabular}

the lesion was 2.4 to $4.2 \mathrm{~cm}$ with an average of $3.2 \mathrm{~cm}$. The patients were randomly divided into the MRI group and the MRI plus MRS group, with ten in each.

\section{Gamma knife radiosurgery}

Following local anesthesia, Lekse11-G stereotactic frame was installed and the lesions were scanned horizontally and coronally at thin slices. Based on this, ${ }^{1} \mathrm{H}-\mathrm{MRS}$ was undertaken using two-dimensional multi-voxel proton MRS using the pointed resolved surface coil spectroscopy. The images were transferred to the computer. OUR-XGD gamma knife was used for establishment treatment. The target volume was defined as the tumor enhanced area plus the surrounding area with a short T1 and a long T2 in the MRI group (Figure 1A), while it was regarded as the tumor enhanced area plus the surround area with a short $\mathrm{T} 1$ and a long $\mathrm{T} 2$, and choline: $\mathrm{N}$-acetyl aspartate index $(\mathrm{CNI}) \geq 1.6$ in the MRI plus MRS group (Figure 1B). Planned parameters included 1-8 isocenters, and $40-55 \%$ isodose curves, 8-16Gy peripheral dose (average $13.5 \mathrm{~Gy}$ ), and 18-30Gy central dose (average 25.5Gy).

\section{Follow-up}

All the patients received clinical examination and MRI every 2-4 months in the follow-up. The 12 months after radiosurgery was the endpoint of the follow up. The treatment was successful if the lesion shrank or did not show progress. Death was considered failure of treatment. The cerebral edema index was defined as the product of length, width, and height of the lesion and the edema scope divided by the product of length, width, and height of the lesion in the T2 or T1 weighted image. Cerebral edema was considered if the index increased after treatment, regardless of clinical symptoms (9).

\section{Statistical analysis}

SPSS 12.0 was used for statistical analyses. The treatment effect and cerebral edema were summarized for two groups. Difference was analyzed in age, sex, prior chemotherapy and radiotherapy, pathologic grading, maximum diameter of the lesion, peripheral dose, maximum diameter of the target volume, effective rate, and cerebral edema rate between two groups. Categorical data were analyzed using Chi-square test, while continual data were analyzed using t test.

\section{RESULTS}

Thirteen (65\%) patients were successfully treated, of whom 6 were in the MRI group and 7 in the MRI plus MRS group. Ten $(50 \%)$ patients suffered from cerebral edema during treatment, including 8 in the MRI group and 2 in the MRI plus MRS group. No significant difference was noted in age, sex, prior chemotherapy and radiotherapy, pathological grading, maximum diameter of the lesion, peripheral dose, and effective rate between two groups. The cases of cerebral edema were significantly fewer in the MRI plus MRS group than the MRI group. In addition, the average maximum diameter of the target volume was smaller in the MRI plus MRS group (Table II). 

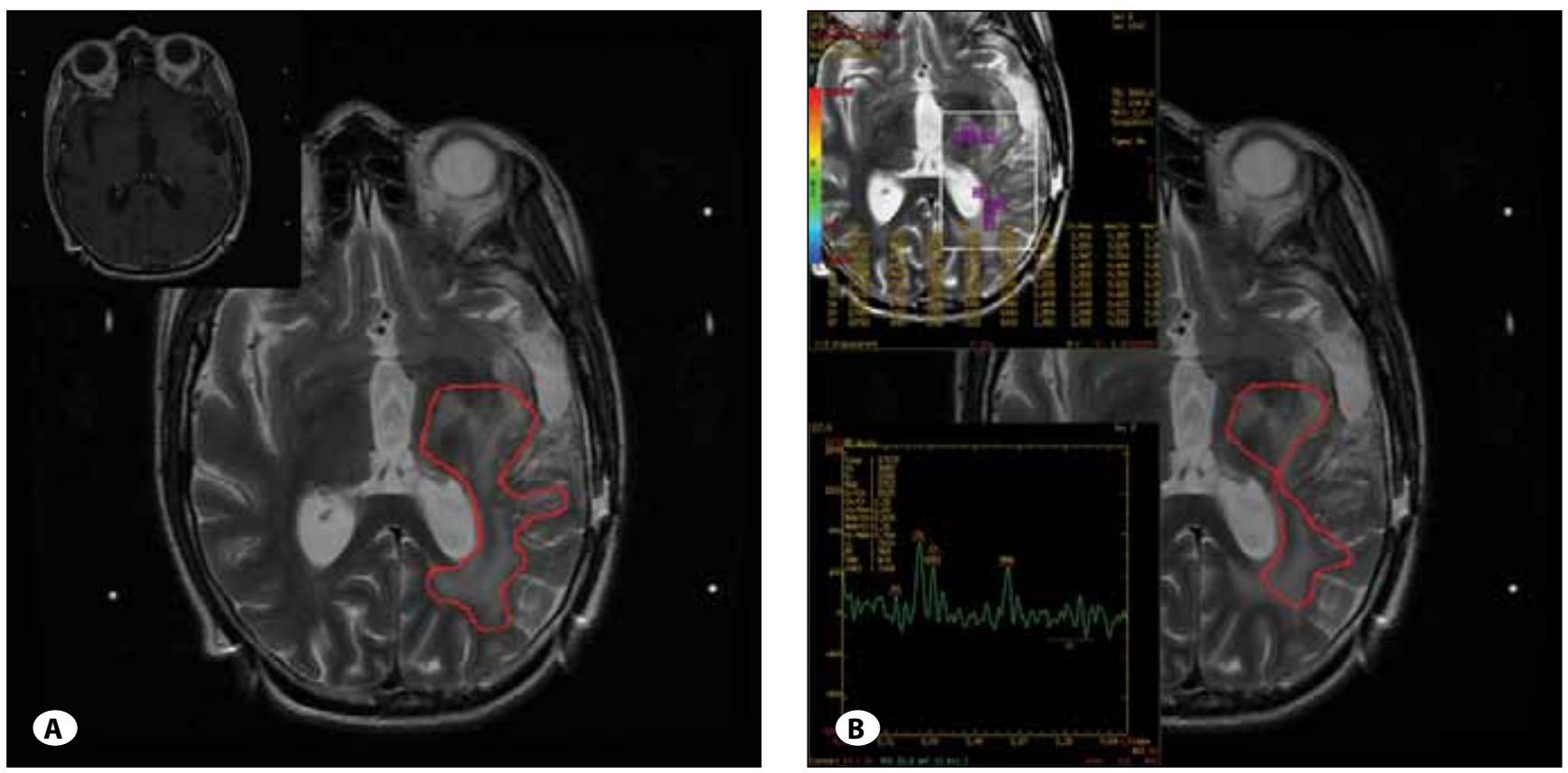

Figure 1: The tumor enhanced lesion of the Grade III Glioma (WHO) had been removed and there was residual in the area with a short T1 and a long T2. A) the MRI group; B) the MRI plus MRS group.

Table II: Comparison of Outcomes Between the MRI Group and the MRI Plus MRS Group

\begin{tabular}{|c|c|c|c|}
\hline Variables & MRI & MRI plus MRS & $\mathbf{P}$ \\
\hline Age (Mean $\pm S D)$ (years) & $40.6 \pm 13.9$ & $49.5 \pm 13.8$ & 0.168 \\
\hline Male patients & 8 & 4 & 0.133 \\
\hline Prior chemotherapy or radiotherapy & 6 & 8 & 1.000 \\
\hline WHO grade III and IV & 4 & 3 & 1.000 \\
\hline Maximum diameter of the lesion $($ Mean $\pm S D)(\mathrm{cm})$ & $3.2 \pm 0.49$ & $3.3 \pm 0.49$ & 0.560 \\
\hline Maximum diameter of the target volume $($ Mean $\pm S D)(\mathrm{cm})$ & $3.2 \pm 0.49$ & $2.8 \pm 0.34$ & 0.043 \\
\hline Peripheral dose (Mean $\pm S D)$ (Gy) & $11.6 \pm 2.45$ & $11.2 \pm 2.39$ & 0.717 \\
\hline Effective cases & 6 & 7 & 0.500 \\
\hline Cases of cerebral edema & 8 & 2 & 0.022 \\
\hline
\end{tabular}

\section{DISCUSSION}

As an accurate radiation technique that kills tumors and protects normal brain tissues dependent on special dose distribution instead of radiation sensitive difference between normal tissue and tumor, radiosurgery is widely used for treatment of glioma, though outcomes differ. For low-grade glioma, radiosurgery achieves surprising efficacy. Park et al. (15) observed that the rate of tumor growth control was 52\%, and the 1-year, 5-year and 10-year progress-free survival was $91.3 \%, 54.1 \%$ and $37.1 \%$, respectively in an average 65-month follow-up after radiosurgery for 25 cases of WHO grade II glioma. Hallemeier et al. (16) also found that radiosurgery showed favorable local control rate for recurrent or nonresected pilocytic astrocytoma. However, for highgrade glioma, there is insufficient evidence for additional benefits from radiosurgery in conditions of no combined external beam radiation therapy or chemotherapy (17). The mechanism underlying this fact is unclear, but is thought to be that high-grade glioma is more invasive, thus resulting in unclear boundaries. It is also reported that radiosurgery is accompanied with a complication rate of $44.8 \%$ (18). Considering the growth of glioma, it is suspected that normal cerebral tissues are involved in the target tissues. So, to improve outcomes and reduce complications of gamma knife radiotherapy, it is essential to define the scope of the lesion for radiosurgery.

Conventional CT and MRI are basis for delineating the scope of glioma. In most circumstances, the scope defined by CT or MRI is not the actual abnormal area of glioma. Burger et al. (2) found that the invasion went beyond the scope delineated by $C T$ after comparing the areas with enhancement and hypodensity on CT with sections for 15 cases of glioblastoma multiforme. Goldman et al. (7) stated that glioma could not be distinguished from normal brain tissues due to invasive 
growth of glioma, though there was a boundary on CT or MRI. Stereotactic biopsy is a reliable technique to identify the interface between the glioma and normal tissues, but it is accompanied by possible complications. In this regard, fluorography, MRS, single-photon emission computed tomography, and positron emission tomography become increasingly important. MRS is developed based on MRI. It reveals cellular metabolism through spectroscopy of cellular chemicals. Multiple lines of evidence show that glioma is characterized by decrease of normal cells, invasive growth, vague boundary between glioma and normal tissues, growth of neuroglial fibers, necrosis and degeneration. Accordingly MRS for glioma contain features such as Cho increase, NAA decrease, and moderate creatin reduction as well as Lac and Lip peaks for highly malignant gliomas $(1,3)$. Some researchers analyzed feasibility of standards for identifying glioma based on change of Cho and NAA. McKnight et al. (12) found that the sensitivity and specificity were $90 \%$ and $86 \%$, respectively, if $\mathrm{CNI} \geq 2.5$ was the criterion to differentiate the glioma and normal tissues. In addition, they showed that average CNI was 6.9, 7.1 and 9.37 for WHO grade II/IV, III/IV and IV/V glioma, respectively, and especially it varied for WHO grade IV/V glioma. Law et al. (11) found that the sensitivity, specificity, positive predictive value and negative predictive value were $74.2 \%, 62.5 \%, 85.6 \%$, and $44.6 \%$, respectively if the CNI cut-point was set to 1.6.

In conventional radiosurgery, the area with a long T1 and a short T2 surround the lesion was included in the target volume. In most cases, the area with abnormal metabolism in MRS is inconsistent with the abnormal area in MRI (12). Pirzkall et al (13) found that the area with a long T2 in MRI was larger than that with abnormal metabolism but did not cover this area, suggesting that MRI alone cannot delineate the target volume accurately and may increase the risks of irradiation and tumor control rate. In our study, based on $\mathrm{MRI}, \mathrm{CNI} \geq 1.6$ in MRS was an additional criterion for defining the target volume. We observed that the tumor control rate was not increased significantly, but the scope of treatment and the risk of cerebral edema were decreased, indicating that the technique facilitates gamma knife radiosurgery. This may be justified by the underlying fact that the target volume defined is equivalent to the actual lesion scope. The technique combines the advantages of conventional MRI for identifying the lesion and the complementary merits of MRS for distinguishing the non-enhanced area and the necrotic tissues.

Though MRS helped to distinguish the glioma from surrounding tissues in our study, many patients witnessed poor tumor control. One possibility is that some isolated lesions cannot even be identified by MRS based on existing metabolic indexes. Thus future efforts should be directed to continuing investigation of other metabolic indexes and criteria. In addition, though emphasis is put on pathology grading and other important factors in our study, there is no radical consistency in glioma types. Future studies are thus justified to validate and improve our results.

\section{CONCLUSION}

Our findings show that ${ }^{1} \mathrm{H}-\mathrm{MRS}$ combined with MRI takes into account both anatomic and metabolic characteristics of glioma. This combination makes it possible to align the target volume with the actual scope of the lesion without adding technical difficulties and reduce complications accompanying with aimless treatment. Regrettably, there is still a hurdle in defining some isolated invasive lesions.

\section{REFERENCES}

1. Alexander A, Murtha A, Abdulkarim B, Mehta V, Wheatley M, Murray B, Riauka T, Hanson J, Fulton D, McEwan A, Roa W: Prognostic significance of serial magnetic resonance spectroscopies over the course of radiation therapy for patients with malignant glioma. Clin Invest Med 29:301-311, 2006

2. Burger PC, Heinz ER, Shibata T, Kleihues P: Topographic anatomy and CT correlations in the untreated glioblastoma multiforme. J Neurosurg 68:698-704, 1998

3. Cha S: Neuroimaging in neuro-oncology. Neurotherapeutics 6:465-477, 2009

4. Chuang CF, Chan AA, Larson D, Verhey LJ, McDermott M, Nelson SJ, Pirzkall A: Potential value of MR spectroscopic imaging for the radiosurgical management of patients with recurrent high-grade gliomas. Technol Cancer Res Treat 6:375-382, 2007

5. Sheehan J, Xu Z: Stereotactic Radiosurgery for recurrent high grade gliomas. World Neurosurgery 76:61-62, 2011

6. Gruber S, Stadlbauer A, Mlynarik V, Gatterbauer B, Roessler K, Moser E: Proton magnetic resonance spectroscopic imaging in brain tumor diagnosis. Neurosurg Clin N Am 16:101-114, 2005

7. Goldman S, Pirotte BJ: Brain tumors. Methods Mol Biol 727:291-315, 2011

8. Henderson MA, Fakiris AJ, Timmerman RD, Worth RM, Lo SS, Witt TC: Gamma knife stereotactic radiosurgery for lowgrade. Astrocytomas Stereotact Funct Neurosurg 87:161-167, 2009

9. Kalapurakal JA, Silverman CL, Akhtar N, Laske DW, Braitman LE, Boyko OB, Thomas PR: Intracranial meningiomas: Factors that influence the development of cerebral edema after stereotactic radiosurgery and radiation therapy. Radiology 204:461-465, 1997

10. Kida $Y$, Yoshimoto $M$, Hasegawa T: Radiosurgery for intracranial gliomas. Prog Neurol Surg 22:122-128, 2009

11. Law M, Yang S, Wang H, Babb JS, Johnson G, Cha S, Knopp EA, Zagzag D: Glioma grading: Sensitivity, specificity, and predictive values of perfusion MR imaging and proton MR spectroscopic imaging compared with conventional MR imaging. AJNR Am J Neuroradiol 24:1989-1998, 2003

12. McKnight TR, von dem Bussche MH, Vigneron DB, Lu Y, Berger MS, McDermott MW, Dillon WP, Graves EE, Pirzkall A, Nelson SJ: Histopathological validation of a three-dimensional magnetic resonance spectroscopy index as a predictor of tumor presence. J Neurosurg 97:794-802, 2002 
13. Pirzkall A, McKnight TR, Graves EE, Carol MP, Sneed PK, Wara WW, Nelson SJ, Verhey LJ, Larson DA: MR-spectroscopy guided target delineation for high-grade gliomas. Int J Radiat Oncol Biol Phys 50:915-928, 2003

14. Soares DP, Law M: Magnetic resonance spectroscopy of the brain: Review of metabolites and clinical applications. Clin Radiol 64:12-21, 2009

15. Park KJ, Kano H, Kondziolka D, Niranjan A, Flickinger JC, Lunsford LD: Early or delayed radiosurgery for WHO grade II astrocytomas. J Neurooncol 103:523-532, 2011
16. Hallemeier $\mathrm{CL}$, Pollock BE, Schomberg PJ, Link MJ, Brown PD, Stafford SL: Stereotactic radiosurgery for recurrent or unresectable pilocytic astrocytoma.Int J Radiat Oncol Biol Phys 83:107-112, 2012

17. Tsao MN, Mehta MP, Whelan TJ, Morris DE, Hayman JA, Flickinger JC, Mills $M$, Rogers CL, Souhami L: The American Society for Therapeutic Radiology and Oncology (ASTRO) evidence-based review of the role of radiosurgery for malignant glioma.Int J Radiat Oncol Biol Phys 63:47-55, 2005

18. Wang YY, Yang GK, Li SY, Baol XF, Wu CY: Prognostic factors for deep situated malignant gliomas treated with linac radiosurgery. Chin Med Sci J 19:105-110, 2004 